\title{
Whistleblowing System Dalam Memutus Rantai Fraud Untuk Mewujudkan Economic Growth (Studi Pada Direktorat Jenderal Pajak Indonesia)
}

\author{
Musmulyadi \\ Institut Agama Islam Negeri Pare-pare \\ Musmulyadi@iainpare.ac.id
}

Fitri Indah Sari

Universitas Hasanuddin

Fitriindah66237@gmail.com

\begin{abstract}
Abstrak The Purpose of this study is to see and know the wistleblowing of goverment systems in breaking the fraud chain in the DJP environment. As we know that fraud is an action that can be used for many parties. Particulary in The DJP enviroment will greatly affect the economy, which means it comes from taxes. Fraud on the DJP is now beginning to be overcome with the invention or mare wistleblowing system aplication by the finance ministry to prevent fraud. This app is created to keep the privacy and privacy whistleblower of fraud. This whistleblowing system aplication was created to break the chain of fraud. This research was conducted by using the metod of studying journals and document related to the theme of search, or in accordance whit the theme of research.
\end{abstract}

\section{Kata Kunci Whistleblowing sistem, fraud, economi growth, Goverment, whistleblower}

\section{PENDAHULUAN}

Whistleblowing merupakan pengungkapan praktik ilegal, tidak bermoral atau melangar hukum yang dilakukan oleh anggota organisasi (baik mantan pegawai ataupun yang masih bekerja) yang terjadi didalam organisasi tempat mereka bekerja (Husniati, Hardi, \& Wiguna, 2017). Whistleblowing menurut KNKG di dalam pedoman sistem pelaporan pelanggaran adalah pengungkapan tindakan pelanggaran atau pengungkapan perbuatan yang melawan hukum, perbuatan tidak etis/ tidak bermoral atau perbuatan lain yang dapat merugikan organisasi atau pemangku kepentingan, yang dilakukan oleh karyawan atau pimpinan organisasi pada pimpinan organisasi atau lembaga lain yang dapat mengambil tindakan atas hal tersebut (Sagara, 2013)). Dalam sebuah organisasi ada beberapa macam hal yang dihindari yaitu salah satunya adalah terjadinya fraud atau kecurangan didalamnya. Kecurangan atau fraud bukan hanya dilakukan oleh orang-orang internal saja bahkan orangorang eksternal atau pihak eksternal seperti suplier pun dapat melakukan fraud atau 
kecurangan. Whistleblowing pertamakali terjadi pada kasus enron yang populer pada abad ke 21.

Seseorang yang biasanya berperan sebagai pelapor pelangggaran dapat disebut sebagai whistleblower atau biasa juga disebut blower. Seorang blower harus memenuhi dua kriteria yaitu yang pertama seorang whistelblower harus menyampaikan atau mengungkapkan laporan pada otoritas berwenang atau kepada media massa atau publik, dengan mengungkap kepada media massa dan publik atau otoritas yang berwenang diharapkan agar dugaan suatu kejahatan dapat diungkap dan terbongkar, Kemudian kriteria kedua menurut Sagara adalah seorang blower adalah orang "dalam" yaitu orang-orang yang mengungkap dugaan pelanggaran dan kejahatan yang terjadi ditempat mereka bekerja karena skandal kejahatan selalu terorganisir maka seorang blower kadang merupakan bagian dari kejahatan dan mafia itu sendiri, dia terlibat dalam skandal dan kemudian mengungkapkan kejahatan yang terjadi (Sagara, 2013).

Seorang Auditor internal juga merupakan blower karna berada dalam internal organisasi. Seorang auidtor yang pernah menjadi blower adalah seorang auditor yang bernama Cynthia Cooper. Cynthia Cooper merupakan salah satu auditor internal pada sebuah organisasi yang bernama Worldcom. Cynthia sendiri menemukan adanya indikasi kecurangan yang terjadi pada laporan keuangan Worldcom. Cynthia berhasil mengungkapkan skandal tersebut hingga membuat Worldcom menyatakan dirinya pailit (Joneta, 2016). Berdasarkan dari kasusu tersebut dapat kita lihat bahwa seorang auditor dapat menjadi seorang blower yang andal dalam memutus rantai fraud dalam sebuah organisasi atau instansi.

\section{LANDASAN TEORI 1. Konsep Reward}

Reward memiliki banyak tujuan dalam pembelajaran tetapi yang penting untuk memperkuat perilaku yang tepat dan memberi umpan balik kepada orang-orang yang telah melakukan dengan benar, reward merupakan konsekuensi yang dapat meningkatkan probabilitas bahwa suatu perilaku akan terjadi .Pada suatu istansi atau organisasi pemberian sebuah reward sangatlah dibutuhkan untuk karyawan sebagai alat untuk memotivasi mereka untuk tetap giat dalam bekerja (Aziz, 2016). Hal seperti itu pun yang seharusnya diterapkan untuk para blower, yaitu memberikan penghargaan atau reward kepada mereka karena mereka telah berhasil mengungkap sebuah kasus kejahatan yang dapat membahayakan intansi atau organisasi.

Reward adalah usaha untuk menumbuhkan rasa diterima (diakui) dilingkungan kerja, yang menyentuh aspek konpensasi dan aspek hubungan para pekerja satu dengan yang lainnya. Seorang blower ketika telah melaporkan sustu hal penyimpangan atau mengungkapkan suatu penyimpangan biasanya akan merasa takut dan minder terhadap lingkungannya, namun hal tersebut sebenarnya dapat diatasi dengan pemberian reward kepada blower tersebut sehingga mereka tetap merasa diterima dilingkungan kerja mereka saat ini serta juga tetap memperbaiki hubunga internal perusahaan (Febrianti, Al-Musaddieq, \& Prasetyo, 2014). 


\section{Konsep Whistleblower}

Whistleblower merupakan orang atau sekelompok orang yang mengungkapkan atau membocorkan sebuah kasus kecurangan atau fraud dalam sebuah instansi atau organisasi, Whistleblower juga biasa disebut sebagai pelapor. Whistleblower adalah seseorang yang melaporkan suatu tindakan melawan hukum, terutama korupsi didalam instansi atau organisasi tempat ia bekerja (Siringoringo, 2015). Pada sebuah organisasi atau instansi biasanya orang-orang yang sering menjadi blower adalah internal dari perusahaan itu sendiri. Seperti yang dikatakan oleh (Sagara, 2013) bahwa pada dasarnya pelapor pelanggaran (whistleblower) adalah karyawan dari organisasi itu sendiri (pihak internal), akan tetapi tidak menutup kemungkinan adanya pelapor yang berasal dari luar instansi atau organisasi (pelanggan, pemasok, dan masyarakat.

Seorang pelapor (whistleblower) dalam mengungkapkan sebuah kasus kecurangan atau perilaku yang melanggar hukum hendaknya memiliki bukti yang cukup serta informasi yang jelas perihal yang dilaporkan sehingga laporan dapat ditindaklanjuti dan dengan mudah dapat ditelusuri, sebab tanpa adanya informasi serta bukti yang cukup dan jelas , maka laporan akan sulit untuk itindaklanjuti dan ditelusuri. Pada prinsipnya seorang whistleblower merupakan "prosocial behaviour" yang menekankan membantu pihak lain dalam menyehatkan sebuah organisasi atau perusahaan, seorang whistleblower memiliki motivasi tertentu untuk mengungkap fakta, seperti pencitraan organisasi,kolegialisme sesama pekerja atau pegawai dilingkungannya bekerja. (Sagara, 2013) . Dalam melakukan whistleblower tentunya akan memiliki dampak tersendiri bagi whistleblower itu sendiri, dampak yang akan diberikan bisa negatif dan biasa pula negatif, dampak positifnya yaitu: pemberian penghargaan, penghindaran kewajiban legal, dan kenaikan pangkat, adapun dampak negatinya adalah salah satunya dapat kehilangan pekerjaan (Setianto, Utami, \& Novianti, 2016).

\section{Theory of Planned Behavior}

TPB atau Theory of Planned Behavior dimana teori ini dicetus oleh (Ajzen, 1991). Dalam teori ini menjelaskan bahwa kita harus bisa memprediksi diri dari niat untuk melakukan suatu perilaku dan juga dari kontrol perilaku yang dirasakan. Karena dari niat seseorang akan dapat melakukan suatu perilaku. Individu atau masyarakat akan melakukan apa saja yang dapat menguntungkan bagi dirinya sehingga individu harus memperbaiki niat yang akan menimbulkan suatu perilaku. Niat seseorang akan berubah seiring dengan interval waktu yang lama. Sehingga perubahan perilaku juga ikut berubah dengan adanya perubahan niat tersebut.

Konsep Theory of Planned Behavior, perilaku yang baik dalam menekankan whistleblowing systemm goverment dalam memutus rantai fraud untuk mewujudkan economic growth ini adalah seseorang yang mampu bertindak berdasarkan intensi atau niatnya hanya jika ia memiliki kontrol terhadap perilakunya. Theory of Planned Behavior ini tidak hanya menekan pada rasionalitas dari tingkah laku manusia, tetapi juga pada keyakinan bahwa target tingkah laku berada di bawah kontrol kesadaran individu itu sendiri. Seseorang yang ingin melakukan suatu tindak kecurangan berasal dari suatu niat yang ada 
dalam dirinya.Sehingga kecurangan dapat dilakukan ketika seseorang sudah memiliki niat di dalam dirinya. Apabila kontrol dalam diri individu tersebut tidak dapat di kontrol dengan baik maka niat untuk melakukan kecurangan tersebut dapat dilakukan. Apabila individu tersebut memiliki niat di dalam dirinya untuk melakukan kecurangan dalam bentuk melakukan fraud maka perilaku untuk melakukan kecurangan dapat direalisasikan karena adanya dorongan dari dalam diri invidu tersebut tanpa adanya kontrol diri yang baik. Tindak fraud yang dilakukan individu tersebut akan berdampak pada pertumbuhan ekonomi dimana dampak yang ditimbulkan dapat menyebabkan jumlah kemiskinan meningkat akibat adanya kecurangan yang dilakukan.

\section{Whistleblowing}

Whistleblowing merupakan suatu tindakan kecurangan atau suatu tindakan yang menyimpang yang mengindikasikan terjadinya pelanggaran hukum yang dapat merugikan segala pihak, baik eksternal maupun internal. Whistleblowing menurut KNKG didalam pedoman sistem pelaporan pelanggaran adalah pengungkapan tindakan pelanggaran atau pengungkapan perbuatan yang melawan hukum, perbuatan tidak etis/ tidak bermoral atau perbuatan lain yang dapat merugikan organisasi atau pemangku kepentingan, yang dilakukan oleh karyawan atau pimpinan organisasi pada pimpinan organisasi atau lembaga lain yang dapat mengambil tindakan atas hal tersebut (Sagara, 2013).

Menurut (Husniati, Hardi, \& Wiguna, 2017)terdapat tiga faktor yang mempengaruhi tindakan Whistlebowing adalah : (1) faktor yang pertama adalah orientasi etika relativisme etis, yaitu teori yang menyatakan bahwa suatu tindakan dapat dikatakan etis atau tidak, benar atau salah, tergantung pada pada pandangan masyarakat itu sendiri, maksudnya adalah masyarakat memiliki keyakinan etis atas dirinya sendiri, (2) faktor yang kedua adalah intensitas moral, intensitas moral dapat dikaitkan dengan konsep persepdi kontrol perilaku dalam teori perilaku terencana, (3) komitmen organisasi, komitmen organisasi merupakan loyalitas seorang karyawan terhadap organisasi atau istansi tempat mereka bekerja, (4) Identitas Profesional merupakan komponen identitas sosial seseorang yang menggaskan bahwa individu mengklasifikasikan dirinya sendiri berdasarkan profesi mereka.

\section{Whistleblowing System}

Whistleblowing System merupakan sebuah aplikasi yang di sediakan oleh kementrian keuangan bagi setiap orang jika memiliki informasi terkait dengan adanya pelanggaran atau penyelewengan dan tindak kejahatan korupsi. Adapun manfaat whistleblowing System) adalah:

1. Tesedianyan cara penyampaian informasi penting dan kritis bagi perusahaan kepada pihak yang harus segera menanganinya secara aman.

2. Timbulnya keenggana untuk melakukan pelanggaran, dengan semakin meningkatnya kesediaan untuk melaporkan terjadinya suatu pelanggaran, karena kepercayaan terhadap sistem pelaporan yang efektif. 


\section{JESYA}

JURNAL EKONOMI \& EKONOMI SYARIAH

Jurnal Ekonomi \& Ekonomi Syariah Vol 3 No 2, Juni 2020

E-ISSN : 2599-3410 | P-ISSN : 2614-3259

DOI : https://doi.org/10.36778/jesya.v3i2.198

3. Tersedianya mekanisme deteksi dini (early warning system) atas kemungkinan terjadinya masalah akibat suatu pelanggaran.

4. Tersedianya kesempatan untuk menangani masalah pelanggaran secara internal terlebih dahulu, sebelum meluas menjadi pelanggaran yang bersifat publik.

5. Mengurangi resiko yang dihadapi organisasi akibat dari pelanggaran baik deri segi keuangan, operasi, hukum, keselamatan kerja, dan reputasi.

6. Mengurangi biaya dalam menangani akibat dari terjadinya pelanggaran

7. Meningkatnya reputasi perusahaan dimata pemangku kepentingan, regulator, dan masyarakat secara umum.

8. Memberikan masukan kepada organisasi untuk melihat lebih jauh area kritikal dan proses kerja yang memiliki kelemangan pengendalian internal, serta untuk merancang tindakan yang diperlukan.

\section{Fraud}

Fraud adalah sebuah aktivitas yang terjadi didalam suatu lingkungan sosial dan mempunyai konsekuensi yang berat pada ekonomi, perusahaan dan individu (Urumsah, Wicaksono, \& Patama, 2016). Kecurangan atau fraud merupakan tindakan yang dengan sengaja melakukan penipuan yang menimbulkan kerugian tanpa disadari oleh pihak yang menjadi korban atau yang dirugikan dan memberikan keuntungan untuk diri sendiri maupun kelompok oleh para pelaku kecurangan. Dimana pihak yang melakukan kecurangan ini hanya semata-mata mementingan kepentingan pribadinya saja . Dalam kondisi ini terlihat bahwa adanya kerja sama yang dilakukan oleh beberapa pihak dalam melakukan suatu kecurangan sehingga ada kerja sama guna memenuhi kepentingan pribadi individu yang melakukan kecurangan. Menurut SAS No. 99, Kecurangan pelaporan keuangan (financial statement fraud) dapat dilakukan dengan :

1. Manipulasi, pemalsuan, atau perubahan catatan akuntansi, dokumen pendukung dari laporan keuangan yang disusun.

2. Kekeliruan atau kelalaian yang disengaja dalam informasi yang signifikan terhadap laporan keuangan

3. Melakukan secara sengaja penyalahgunaan prinsip - prinsip yang berkaitan dengan jumlah, klasifikasi, cara penyajian atau pengungkapan.

Fraud yang dimaksudkan dalam mewujudkan pertumbuhan ekonomi disini yaitu tindak korupsi. Dengan adanya tindak korupsi ini akan berdampak pada pertumbuhan ekonomi. Dimana dampak tersebut yaitu tingkat kemiskinan meningkat dan berkurangnya kesejahteraan masyarakat. Telaah fraud akan menekan tindak korupsi yang dapat dilakukan oleh individu. Sehingga dengan adaya penekanan fraud ini akan meningkatkan pertumbuhan ekonomi. Tindak korupsi berpengaruh dalam mewujudkan perkembangan pertumbuhan ekonomi. Dengan berkurangnya tindak korupsi yang dilakukan maka kemiskinan akan berkurang dan juga akan meningkatkan kesejahteraan masyarakat. Walaupun tindak korupsi susah dihilangkan, namun upaya untuk menekan ketindakan yang lebih kecil dapat dilakukan. Pada penelitian ini juga menggunakan Triangle Fraud Theory sebab pada penelitian ini juga membahas mengenai fraud pada organisasi hubungannnya dengan 
whistleblowing. Teori fraud triangle yang dikembangkan oleh Cressey (1953), yang mengatakan bahwa fraud disebabkan oleh tiga faktor utama, yaitu: Pressure atau tekanan,(2) Opportunity atau peluang/kesempatan, (3) Rationalization atau pembenaran.

\section{Economic Growth}

Pertumbuhan ekonomi adalah indikator yang dipergunakan untuk melihat keberhasilan pembangunan, dalam pembangunan yang dimaksud dapat mengatasi tingkat kemiskinan (Siregar \& Wahyuniarti, 2008). Pertumbuhan ekonomi merupakan pengukuran suatu prestasi dari perkembangan suatu perekonomian (Supartoyo, Tatuh, \& Sendouw, 2013). Pengukuran akan kemajuan suatu perekonomian memerlukan alat ukur yang tepat seperti, alat ukur pertumbuhan ekonomi yaitu Produk domestic bruto atau ditingkat regional disebut produk domestic regional bruto (PDRB) yaitu jumlah barang atau jasa yang dihasilkan oleh suatu perekonomian dalam jangka waktu satu tahun dan dinyatakan dalam harga pasar. Pertumbuhan ekonomi diartikan sebagai kenaikan GDP tanpa memandang apakah kenaikan itu lebih besar atau lebih kecil dari tingkat pertumbuhan penduduk atau apakah perubahan struktur ekonomi terjadi atau tidak (Prishardoyo, 2008). Jika ingin mengetahui tingkat pertumbuhan ekonomi kita harus membandingkan pendapatan nasional dari tahun ke tahun. Dalam membandingkannya harus disadari bahwa perubahan nilai pendapatan yang nasional yang terjadi dari tahun ke tahun disebabkan oleh dua faktor yaitu perubahan tingkat kegiatan ekonomi dan perubahan harga-harga. Adapun tingkat pertumbuhan ekonomi dari tahun 2011-2016 ,yaitu, pada tahun 2011 tingkat pertumbuhan ekonomi mencapai 6,5\%, pada tahun 2012 mencapai 6,2\%, pada tahun 2013 tingkat pertumbuhan ekonomi mencapai 5,78\%, pada tahun 2014 mencapai 5,02\%, pada tahun 2015 mencapai 4,88\%, dan pada tahun 2016 mencapai 5,02\%. (BI,2016). Adanya pengaruh dari faktor yang kedua tersebut disebabkan oleh penilaian pendapatan nasional menurut harga yang berlaku pada tahun yang bersangkutan. Suatu perekonomian dikatakan mengalami pertumbuhan atau perkembangan jika tingkat kegiatan ekonomi yang dicapai lebih tinggi dari waktu sebelumnya.

Faktor-faktor yang mempengaruhi pertumbuhan ekonomi, yaitu:

a. Tanah dan kekayaan alam lain.

b. Jumlah dan mutu penduduk dan tenaga kerja.

c. Barang-barang modal dan tingkat teknologi

d. Sistem sosial dan sikap masyarakat

e. Luas pasar sebagai sumber pertumbuhan

f. Jumlah dan mutu penduduk dan tenaga kerja

\section{Whistleblower Pada Whistleblowing System.}

Whistleblower kaitannya dengan Whistleblowing Sistem adalah Whistleblower memiliki peranan penting didalamnya, sebab tanpa adanya whisteblower, maka whistleblowing system juga tidak dapat diajalnkan. Whistleblowing System dibuat guna sebagai sarana yang digunakan para blower untuk melaporkan sebuah tindakan kejahatan dan kecurangan yang dilakukan oleh karyawan dalam sebuah instansi atau organisasi. Whistleblowing System dibuat untuk menjaga kerahasiaan dari orang-orang yang melakukan 
whistleblower sehingga ketika ia melaporkan suatu kasus fraud maka kerahasiaan pelapor akan terjamin, sehingga dalam melaporkan suatu tindakan kecurangn seseorang tidak akan takut lagi akan terkena dampak dari hal yang ia laporkan.

Beberapa unsur dan isu penting dalam penerapan whistleblowing System, yaitu membangun budaya amanah dan keterbukaan, metode dan saluran yang disediakan, pengaduan atau tanpa dengan identitas atau tanpa identitas, ketidakwajaran atau penyimpangan yang dapat dilaporkan, investigasi, tindak lanjut, dan prosedur pelaporan, jenis pembalasan yang dilarang dan kebijakan terkait imunitas whistleblower dari penegakan disiplin dan tuntutan hukum (Siringoringo, 2015). Dengan adanya whistleblowing System diharapkan dapat mengurangi tingkat fraud dalam sebuah instansi atau organisasi, serta semakin banyaknya orang-orang baik internal maupun eksternal perusahaan yang tidak hanya diam ketika melihat sebuah kecurangan dalam organisasi atau istansi sebab, dengan adanya whistleblowing System maka keamanan serta kerahasiaan mereka dapat terjaga sehingga mereka tidak lagi takut akan dampak negatif yang akan mereka terima misalnya saja kehilangan pekerjaan.

\section{Whistleblowing System Goverment Dalam Memutus Rantai Fraud}

Whistleblowing system goverment merupakan sebuah aplikasi yang dibuat dan dirancang sebagai sebuah aplikasi yang dapat dijadikan sebagai sarana oleh para karyawan ataupun pihak eksternal dalam sebuah organisasi untuk melaporkan sebuah tindakan penyimpangan yang melanggar, yang mana tingkat kerahasiaan blower dapat terjamin aman. Terdapat empat unsur yang harus ada dalam whistleblowing system goverment yaitu: (1) whistleblower yaitu seseorang yang berani melaporkan tindak kejahatan atau kecurangan yang ada dalam sebuah organisasi yang dapat melanggar hukum serta merugikan banyak orang. (2) Sarana yang memadai, sarana yang memadai disini yang dimaksud adalah sarana yang efektif dan efisien yang dapat diguanakn oleh blower dalam melaporkan tindak kecurangan yang terjadi pada organisasi atau istansi tempat mereka bekerja, sarana yang efisien ini harus memiliki tingkat keamanan yang tinggi sehingga dapat menjamin keamanan blower.(3) Penanganan pengaduan, salah satu unsur yang juga penting adalah adanya penanganan pengaduan yang baik, yaitu aduan-aduan yang diterima oleh blower harud ditangani dengan baik dan juga harus ditangani oleh pihak-pihak yang berwenang yang dapat mengusut kasus tersebut secara tuntas. (4) Jaminan perlindungan, jaminan perlindungan dibutuhkan oleh para pelapor kasus kecurangan , sebab tanpa adanya keamanan yang memadai maka akan sulit mengungkap informasi-informasi yang diketahui oleh karyawan.

Whistleblowing system goverment dapat memutus rantai fraud apabila segala unsurunsur yang telah dipaparkan diatas dapat terpenuhi, sebab dengan terpenuhinya unsur-unsur diatas maka pengungkapan kasus melalui informasi-informasi dari blower dapat dengan mudah didapatkan, sebab tidak ada lagi rasa takut yang dialami oleh pelapor. Selain itu, para pembuat kecurangan atau tindakan menyimpang akan merasa takut untuk melakukan fraud didalam instansi pemerintahan, sehingga dengan adanya whistleblowing system goverment diharapkan dapat menjadi salah satu alasan untuk seseorang untuk tidak melakukan fraud sehingga kasus fraud akan dapat dikurangi. 


\section{Penelitian Terdahulu}

Pada lingkungan direktorat jenderal pajak, yang mana hasil penelitian yang didapatkan ialah penggunaan whistleblowing system sudah cukup baik pada DJP dan hampir seluruh aspek kebijakan sudah sesuai dengan literatur penggunaan whistleblowing system, akan tetapi bebrapa kendala masih sering terjadi seperti pemahaman mengenai whistleblowing system serta pedoman mengenai penggunaan whistleblowing system (Lastika \& Purwatiningsih, 2015).Kota bekasi mengenai whistleblowing System terhadap kepatuhan wajib pajak yang mana tujuan dari penelitian ini adalah mengenai pengaruh whistleblowing System pada lingkungan DJP (Siringoringo, 2015). Penelitian ini merupakan penelitian kuantitatif kausalitas karena penelitian ini adalah untuk menguji pengaruh variabel-variabel independen terhadap variabel dependen dan bagaimana pengaruhnya apabila ada variabel yang memoderasi variabel independen dan variabel dependen tersebut. Pada penelitian ini peneliti tidak banyak mengambil pusing mengenai sampel sebab sampel yang diambil adalah siapa saja yang ada dilokasi. Hasil penelitian yang didapatkan adalah whistleblowing system dalam lingkungan DJP berpengaruh positif dan signifikan terhadap kepatuhan wajib pajak, maka dari itu whistleblowing system harus tetap dipertahankan.

Penelitian ini berbeda dengan penelitian yang dilakukan oleh peneliti-peneliti sebelumnya. Semakin besar wilayah suatu provinsi dari fraud maka akan semakin mendorong pertumbuhan ekonomi provinsi tersebut (Nawatmi, 2013). Oleh karena itu, provinsi-provinsi tersebut bisa menjadi pendorong bagi pemerintahn setempat maupun pusat untuk segera menegakkan hukum seadil-adilnya sehingga bisa mendorong pelaku di provinsi tersebut untuk 'bersih-bersih lingkungan' karena dengan semakin bersih provinsi-provinsi tersebut dari fraud, maka akan semakin meningkatnya economich growth. Maka peneliti ini memandang fraud sebagai penghambat untuk perkembangan pertumbuhan ekonomi. Dalam penelitian (Swaleheen, Mushfic, \& Dean, 2017) tentang Economic Freedom, Coruption and growth dengan data panel 60 negara, menunjukkan bahwa fraud mempengaruhi pertumbuhan secara tidak langsung dengan intermediasi economic freedom. Negara-negara dengan economic freedom yang rendah maka fraud mengurangi pertumbuhan ekonom, dan sebaliknya jika economic freedom tinggi maka fraud meningkatkan pertumbuhan ekonomi. Penelitian yang dilakukan oleh Swaleheen dan Stansel (2007) tentang Economic Freedom, Coruption and growth dengan data panel 60 negara, menunjukkan bahwa korupsi mempengaruhi pertumbuhan secara tidak langsung dengan intermediasi economic freedom. Negara-negara dengan economic freedom yang rendah maka korupsi mengurangi pertumbuhan ekonomi, dan sebaliknya jika economic freedom tinggi maka korupsi meningkatkan pertumbuhan ekonomi.

\section{METODE PENELITIAN}

Jenis penelitian yang digunakan dalam penelitian ini adalah penelitian kualitatif. Adapun jenis dan sumber data yang digunakan dalam penelitian ini adalah data sekunder (Secondary data). Sumber data sekunder meliputi hasil penelitian dan kajian terdahulu yang dianggap relevan untuk kajian ini.. Adapun tekhnik yang digunakan dalam pengumpulan data ini 
adalah berupa studi pustaka dan melalui internet searching. Jenis penelitian yang digunakan adalah penelitian kualitatif yang berdasarkan pada pendekatan paradigma interpretif. Penelitian ini menggunakan fenomenologi sebab pendekatan fenomenologi juga merupakan sebuah studi yang membahas mengenai kesadaran manusia, sedangkan pada penelitian ini juga membahas mengenai bagai mana menumbuhkan kesadaran pada lingkungan direktorat jenderal pajak mengenai bahaya yang di timbulkan dari fraud serta penting Wistleblowing System. Instrumen penelitian yang dapat membantu atau memudahkan peneliti dalam melakukan penelitian seperti alat tulis menulis, selain itu instrumen-instrumen lain yang dapat digunakan untuk menggambarkan suatu objek seperti handphone, laptop, kuota, dll. Proses pengolahan data dan analisis data dilakukan dengan tiga tahap, yaitu: reduksi data, penyajian data dan penarikan kesimpulan.

\section{HASIL DAN PEMBAHASAN}

\section{Whistleblowing Sistem Dalam Memutus Rantai Fraud}

Fraud atau kecurangan adalah tindakan yang dengan sengaja melakukan penipuan yang menimbulkan kerugian tanpa disadari oleh pihak yang menjadi korban atau yang dirugikan dan memberikan keuntungan untuk diri sendiri maupun kelompok oleh para pelaku kecurangan. Dimana pihak yang melakukan kecurangan ini hanya semata-mata mementingan kepentingan pribadinya saja. Whistleblowing system goverment merupaka sebuah sistem yang dibuat oleh instansi pemerintahan dalam memutus rantai fraud untuk mewujudkan economi growth terkhusu pada instansi perpajakan. Fraud memberikan efek yang merugikan pada roda pertumbuhan ekonomi dan pembangunan berkelanjutan secara jangka panjang. Fraud selalu menyebabkan situasi sosial-ekonomi tak pasti (uncertenly). Ketidakpastian ini tidak menguntungkan bagi pertumbuhan ekonomi dan peluang bisnis yang sehat. Selalu terjadi asimetris informasi dalam kegiatan ekonomi dan bisnis. Sektor swasta sering melihat ini sebagai risiko terbesar yang harus ditanggung dalam menjalankan bisnis, sulit diprediksi bahwa Return of Investment (ROI) yang dapat diperoleh karena biaya yang harus dikeluarkan akibat fraud sulit diprediksi.

Dalam pemerintahan whistleblowing sistem salah satunya digunakan dalam instansi perpajakan, sebab whistleblowing sistem merupakan sebuah alat yang digunakan untuk mengatasi serta mendeteksi kebocoran-kebocoran yang dilakukan oleh seorang dimana dalam rangka mencegah serta menanggapi kecuranagn-kecuranagn yang kemungkinan terjadi pada sekitaran direktorat jenderal pajak (DJP) melalui partisipasi dari msyarakat sebagai whistleblower.Pada tanggal 19 Agustus 2011 Direktorat Jenderal Pajak mengeluarkan Peraturan per 22/PJ/2011 tentang kewajiban untuk melaporkan dan penanganan pelaporan atas pelanggaran (whistleblowing) di lingkungan DJP. Whitleblowing System sendiri dibangun untuk membangun kembali kepercayaan masyarakt terhadap DJP, yang juga dapat mengubah budaya masyarakat yng tadinya hanya diam kemudian diubah menjadi korektif, atau dalam kata lain juga turut aktif dalam memberantas kecurangankecurangan.

\section{Whistleblowing Sistem Goverment Untuk Mewujudkan Economic Growth}


Pajak merupakan sumber pendapatan terbesar bagi negara, sehingga whistleblowing system sangat tepat digunakan pada lingkunga DJP, hal tersebut dikarenakan ketika fraud terjadi pada lingkungan DJP maka hal yang kemungkinan terjadi adalah dampak yang paling utama ditimbulkan pada roda pemerintahan, seperti laju perekonomian negara, sehingga juga akan berdampak pada masyarakat luas. Peningkatan perekonomian suatu negara akan dapat dilihat dari tingkat kesejahteraan dari masyarakatnya, sedangkan salah satu faktor yang dapat digunakan pemerintah untuk mensejahterakan masyarakatnya adalah dari perpajakan. Penerapan whistleblowing system pada DJP diharapkan dapt memberikan dampak yang lebih baik terhadap pencegahan dan pendeteksi terjadinya fraud. Sebab seperti yang kita ketahui pajak merupakan pendapatan terbesar negara, sehingga jika fraud terjadi pada lingkungan DJP maka dapat dikatakan bahwa ecomi growth tidak dapat tercapai dan bahkan akan berdampak negatif pada roda pertumbuhan ekonomi negara. Fraud memberikan efek yang merugikan pada roda pertumbuhan ekonomi jangka panjang dan pembangunan berkelanjutan.

\section{Langkah Mengatasi Fraud dengan Wistleblowing Sistem}

Whistleblowing System merupakan sebuah aplikasi yang di sediakan oleh kementrian keuangan bagi setiap orang jika memiliki informasi terkait dengan adanya pelanggaran atau penyelewengan dan tindak kejahatan korupsi.

Whistelblowing system memang dibuat untuk mendeteksi terjadinya fraud pada sebuah instansi. Seiring dengan berkembangnya kemajuan teknologi dan perkembangan informasi yang ada maka tingkat kecurangan pun semakin tinggi dan bervariasi. Jenis - jenis kecurangan untuk setiap negara berbeda- beda tergantung bagaimana hukum dari negara tersebut. Sehingga untuk mengatasi hal tersebut maka diperlukan adanya keahlian audit investigative atau yang lebih dikenal dengan istilah fraud auditing (pemeriksa kecurangan) untuk mencengah, mendeteksi dan mengungkapkan kecurangan seperti salah saji laporan keuangan, penggelapan dana atau korupsi, pasar uang, mark-up, kejahatan sektor asuransi, penyuapan dalam bisnis dan lain- lain. Komite anti kecurangan diharapkan dapat mencapai zero fraud dalam perusahaan.

\section{KESIMPULAN}

Whistleblowing system dalam memutuskan rantai fraud untuk mewujudkan economi growth khusunya pada instansi perpajakan dapat memberikan pengaruhyang signifikan terhadap kepeatuhan wajib paja serta terhadap pada peningkatan economi growth sebuah negara, hal tersebut dikarenakan. Pajak merupakan penghasilan terbesar negara, sehingga dengan adalanya Whistleblowing system dalam instansi perpajakan dapat sebagai alat yang dapat mendeteksi serta mencegah terjadinya fraud. Fraud yang diakibatkan dari pajakn akan sangat berdampak negatif terhdap roda pertumbuhan perekonomian negara. Economi growth hanya bisa terealisasi ketika fraud dapat diminimalisir, salah satu cara yang dilakukan oleh pemerintah yaitu dengan meluncurkan aplikasi whistleblowing system.

Whistleblowing system memungkinkan dapat berkurangnya fraud, sebab dengan adanya aplikasi ini , masyarakat akan lebih mudah melaporkan tindak kecurangan yang terjadi, tanpa 
adanya rasa takut akan rasa aman dan peekerjaannya, sebab wistleblowing system menjamin kerahasiaan data dari whistleblower sehingga diharapkan akana lebih banyak lagi masyarakat yang dapat melaporkan hal-hal yang melanggar hukum seperti fraud misalnya, sehingga economi growth dapat dicapai.

\section{UCAPAN TERIMAKASIH}

Whistleblowing system merupakan sebuah aplikasi yang dikeluarkan oleh kementrian keuangan dalam rangka untuk mengurangi terjadinya fraud, khususnya pada instansi pemerintahan. Dalam proses pelaksanaanya whistleblowing system dapat diakses dimana saja dengan membuka laman www.wise.depkeu.go.id. Dalam penggunaannya whistleblowing system sudah memberikan efek yang baik terhadap pencegahan terjadinya fraud.

References

Ajzen, I. (1991). The Theory of Planned Bahavior. Organizational Behavior and Human Decision Processess, 51-62.

Aziz. (2016). Reward-Punishment Sebagai Motivasi Pendidikan (Perspektif Barat dan Islam). Cendekia, 88-89.

Febrianti, S., Al-Musaddieq, M., \& Prasetyo, A. (2014). Pengaruh Reward dan Punishment Terhadap Motivasi Kerja Serta Damaknya Terhadap Kinerja. Jurnal Administrasi Bisnis, 1-9.

Husniati, H. S., Hardi, \& Wiguna, M. (2017). Faktor-faktor Yang Mempengaruhi Instensi Untuk Melakukan Whistleblowing System Internal. JOM Fikon, 1123-1237.

Joneta, C. (2016). Pengaruh Komitmen Profesional dan Pertimbangan Etis Terhadap Intensi Melakukan Whistleblowing: Locus of Control Sebagai Variabel Moderasi . JOM Fekon, 735-748.

Lastika, G., \& Purwatiningsih. (2015). Evaluasi atas Implementasi Whistleblowing Sysrtem Sebagai Mekanisme Pnerapan Good Publik Governance: Studi KAsus Direktorat Jendral Pajak Tahun 2012. Jurnal Akuntansi , 207-224.

Nawatmi, S. (2013). Korupsi dan Pertumbuhan Ekonomi- tudi Empiris 33 Provinsi Di Indonesia. Dinamika Akuntansi Keuangan dan Perbankan, 1-10. 


\section{JESYA}

JURNAL EKONOMI \& EKONOMI SYARIAH

Jurnal Ekonomi \& Ekonomi Syariah Vol 3 No 2, Juni 2020

E-ISSN : 2599-3410|P-ISSN : 2614-3259

DOI : https://doi.org/10.36778/jesya.v3i2.198

Prishardoyo, B. (2008). Analisis Tingkat Pertumbuhan Ekonomi dan Potensi Ekonomi Terhadap Produk Domestik Regional Bruto (PDRB) Kabupaten PAti TAhun 2002005. Jurnal Ekonomi dan Kebijakan, 1-10.

Sagara, Y. (2013). Profesionalisme Internal Auditor dan Instensi Melakukan Whistleblowing. Jurnal Liquidity, 34-44.

Setianto, V. Y., Utami, I., \& Novianti, S. (2016). Pelaporan Pelanggaran Dalam Tekanan Ketaatan dan Kepercayaan Pada Pimpinana . Jurnal Ekonomi dan Bisnis, 485-510.

Siregar, H., \& Wahyuniarti, D. (2008). Dampak Pertumbuhan Ekonomi Terhadap Penurunan Jumlah Penduduk MIskin. Jurnal Ekonomi Politik dan Keuangan, 23-40.

Siringoringo, W. (2015). Pengaruh Penerapan Good Governance dan Whistleblowing Sistem Terhadap Kepatuhan Wajib Pajak Orang Pribadi dengan Resiko Sanksi Pajak Sebagai Variabel Moderating. Jurnal Akuntansi, 207-224.

Supartoyo, Y. H., Tatuh, J., \& Sendouw, R. H. (2013). Pertumbuhan Ekonomi dan Karakteristik Daerah: Kasus Indonesia. Buletin Ekonomi Moneter dan Perbankan, 319.

Swaleheen, Mushfic, \& Dean, S. (2017). Economic Freedom, Corruption, and Growth. Cato Jurnal, 20-30.

Urumsah, D., Wicaksono, A. P., \& Patama, A. J. (2016). Melihat Jauh Ke Dalam: Dampak Kecerdasan Spiritual Terhadap Niat Melakukan Kecurangan . Jurnal Alkuntansi dan Auditing Indonesia, 40-52. 